South African Journal of Geomatics, Vol. 5, No. 1, February 2016

\title{
Land allocation, boundary demarcation and tenure security in tribal areas of South Africa
}

Simon Hull, Tshepiso Sehume, Sibonakaliso Sibiya, Lusanda Sothafile, and Jennifer Whittal

Geomatics Division, University of Cape Town, Cape Town, South Africa, simon.hull@uct.ac.za

\section{DOI: http://dx.doi.org/10.4314/sajg.v5i1.5}

\begin{abstract}
This study investigates land allocation processes, boundary demarcation, and associated land tenure security in tribal areas of South Africa. The research design is that of a descriptive multiplecase study to interrogate indigenous knowledge in this area. Four themes related to customary land allocation processes in South Africa have emerged from the data: Applicant, Authority, Acceptance and Allocation. These themes are used as the basis for comparison across the cases. The case studies are also used to test a published conceptual model of land tenure security. The results suggest that tenure in the study areas is secure overall. The study concludes that the processes of land administration and the systems used to demarcate boundaries are (mostly) suitable to protect land rights and thus provide security of land tenure. Also the tested conceptual model of land tenure security can be used to indicate the state of tenure security for a particular case, though improvements are suggested.
\end{abstract}

\section{INTRODUCTION}

In South Africa, land in urban areas and most commercial farms are formally surveyed, well defined and recorded in a formal cadastre (Riba, 2010) that has been described as being equal to the best in the world (Zevenbergen, 2002). By contrast, many people in peri-urban and rural areas occupy and use land under a system of rights that is conveyed through oral tradition and not documented under the formal cadastre. This means they are not formally recognized as legal holders of rights to this land (Ziqubu, Cousins \& Hornby, 2001; Cousins \& Hornby, 2006). Instead, indigenous knowledge systems are used to allocate land rights and define property boundaries. These parcel boundaries are rarely officially recorded. The relevant communities depend on memory and reference to natural and artificial features to define plots of land, which could result in uncertainty regarding the location of boundaries (Ibid.).

Some of the drivers of cadastral development and land administration reform include response to climate change, disaster management, urbanisation, and the need to extend the cadastre to all regions (Burns et al., 2006; Bennett et al., 2010; Hull \& Whittal, 2013). It is to the last of these drivers that this paper speaks. Extending the cadastre should be done with cognisance of existing tenure if it is to be effective and sustainable (Burns et al., 2006; Williamson et al., 2010; Fox, 2015). Hence indigenous boundaries and indigenous knowledge thereof will need to be taken into account 
in the extension of the formal cadastre to customary regions. A sensitive approach is required, with due regard for the existing status quo of land allocation, if institutional multiplicity is to be avoided (Törhönen, 2004; van Leeuwen, 2014). An understanding of existing local norms and practice, which may include intricate social dynamics, could also foster good land governance (see e.g. Barry \& Danso, 2014). Consequently the main objective of this research is to describe indigenous knowledge systems (IKS) being used in some tribal areas of South Africa to allocate land rights and define the corresponding physical boundaries of land for occupation and use. A secondary objective of this research is the assessment of IKS in their ability to deliver land tenure security. Here, a conceptual and as-yet untested model of rural land tenure security developed by Simbizi, Bennett \& Zevenbergen (2014) is used to evaluate the degree of tenure security in the case study areas. Concurrently the usefulness and applicability of the model are also tested, with consequent suggestions for its improvement.

The paper begins with an exploration of the relevant concepts such as indigenous knowledge systems, land administration systems, and aspects of land tenure as relevant to these cases. The conceptual model of rural land tenure security in sub-Saharan Africa (Simbizi, Bennett \& Zevenbergen, 2014) is briefly explained. The multiple-case study is then presented followed by the research findings. The conceptual model is then used to evaluate the state of tenure security in the cases after which the authors reflect on this model and propose some improvements thereof.

\subsection{Indigenous Knowledge Systems (IKS)}

Indigenous knowledge (also called Traditional Knowledge (Twarog \& Kapoor, 2004)) is defined as knowledge that is common in people who identify themselves as indigenous to a particular area (Masango, 2010), including tangible and intangible aspects of cultural identity (Department of Science and Technology, 2015). The knowledge is acquired through past experiences, customary practices, and through observations of these experiences. It is shared amongst local communities, and it evolves over time through generations. In this regard the authors note that in post-colonial countries like South Africa, there is no 'pure' indigenous knowledge. Rather the IKS used reflects both customary practices and more modern, external influences.

Indigenous knowledge systems refer to the rules and principles adopted by local communities to define unique cultural practices. IKS are important because they provide strategies for dealing with and solving these unique issues (Gorjestani, 2004). They also represent a source of cultural pride, are vital to decision-making at a local level, and contribute to empowering the cultural systems and history of indigenous people. Indigenous knowledge is passed on from generation to generation, often by word of mouth (Owusu-Ansah \& Mji, 2013). Because this indigenous knowledge is not always written down it runs the risk of being overlooked by 'Western' communities (Owusu-Ansah $\& \mathrm{Mji}, 2013$ ) and is vulnerable to being exploited for financial gain (Masango, 2010). 


\subsection{Land administration systems}

The context of this study is IKS related to land allocation and boundary demarcation. As such it falls within the broader field of land administration systems (LAS) research. Adopting Williamson et al.'s (2010) broad definition of LAS, in the context of this study land administration includes less formal, communal, and tribal administration of land. The processes of land allocation under investigation include the ways people organise, manage and think about land within tribal institutions.

Four components of land administration are investigated: 1) the processes of allocating land parcels to potential rights-holders (individual, family or community), 2) the procedures of demarcating land boundaries within a tribal jurisdiction, 3) the mechanisms of solving conflicts concerning property boundaries, land use and other land-related rights, restrictions and responsibilities (RRRs), and 4) land tenure security arising as a product of the first three components. These components all feed into the land tenure function of the land management paradigm (Enemark, 2005; Williamson et al., 2010).

\subsection{Rural land tenure in South Africa}

Land tenure in South Africa is influenced by politics, race, location and traditions (Weideman, 2004). There are currently a variety of tenure systems in South Africa (Cousins \& Hornby, 2006), which Törhönen (2004) refers to as multi-layered tenure, which is linked to insecurity of land tenure (van Asperen, 2014). In rural areas, communal tenure is said to be the predominant tenure system (Kitchin \& Ovens, 2013), and the land is legally owned by the State (Weideman, 2004) under the administration of traditional councils (Kitchin \& Ovens, 2013) and therefore the traditional authorities continue to play a major role in allocating land to rural people.

During the apartheid period, Black people in rural areas of South Africa were not able to own land; they were only able to occupy or legally use land (Riba, 2010), although there were exceptions. A use right, called Permission to Occupy (PTO), was granted to the head of a household allowing him or her to occupy and use a certain piece of land. The system of issuing PTOs is still active in some regions of the country as the basic system of land allocation, despite being abolished in 1994 (Cousins, Pollard \& du Toit, 2007), as evidenced in the cases studied here. A PTO is acquired through a personal contract with the local government and traditional authorities. The rights conferred were considered to be personal rights and hence could not be registered in the official Deeds Registry. But Louw (2013) makes the case that it should be simple to convert such forms of apartheid-era title to freehold, although this has not yet happened.

\subsection{A conceptual model of rural land tenure security}

Effective land administration is the key to secure land tenure (Ziqubu, Cousins \& Hornby, 2001). Since the two are highly correlated, an investigation into the processes of land administration, specifically with reference to land allocation, is simultaneously an investigation into tenure security. Hence a conceptual model of land tenure security (Simbizi, Bennett \& Zevenbergen, 2014) was 
used to assess the security of land tenure in the study areas. The model was developed to encapsulate, in a holistic manner, the land tenure security in the rural areas of sub-Saharan Africa. It is based on the understanding that land tenure security is an emergent property of a land tenure system, since it is a function of the interaction of the system's elements as a whole. These elements include people, social and public institutions, the continuum of land rights and restrictions, and land and information about land. Land tenure security is explained by the interactions between these elements (Ibid.). Space does not allow for a detailed description of the model, and interested readers are directed to Simbizi, Bennett \& Zevenbergen (2014).

There are three aspects of the model that we feel warrant further attention. The first is whether or not the five elements used in the model do exist in every rural setting in sub-Saharan Africa, as claimed. Secondly the use of a binary checkbox to indicate absolutely whether or not there is a positive interaction between elements is questioned. We hypothesise that these interactions might not be as simple as a 'yes' or 'no' and that there are many variables influencing each interaction. Instead a five-point Likert scale is introduced in place of the checkbox to accommodate degrees of negativity and positivity (see e.g. Törhönen, 2004; Agunbiade, Rajabifard \& Bennett, 2014), as shown in Figure 2, where (1) represents no interaction between elements; (2) represents poor or negative interaction between elements; (3) represents neutral interaction (neither good nor bad); (4) represents good or positive interaction between elements; and (5) represents no room for improvement.

Lastly, we are uncomfortable with the element designated 'continuum of land rights and restrictions' as this brings to mind the UN model (UN-HABITAT, 2008), which has been critiqued and adapted by Whittal (2014), among others. But it appears that Simbizi et al (2014) are not referring to the UN model and instead make mention of a range of concurrent rights and restrictions to land. We thus propose that this element would be better labelled as 'Land rights and restrictions'.

\section{CASE STUDY AREAS}

Space does not permit for a full presentation of each case study, and interested readers are invited to contact the principal author for further information. The cases investigated are the Xhosa tribe of Matolweni Village, near Idutywa in the Eastern Cape, two Zulu tribal jurisdictions (KwaMvula and KwaSishwili) in the Ulundi area of KwaZulu-Natal, and the Tswana tribe of Dinokana in the North West Province (see Figure 1). These case study areas were chosen (1) because they are the homes of three of the researchers, who were able to act as participant researchers as they are known by the respective communities and speak the local languages, and (2) for their theoretical replication: there should be differences based on the different (tribal) contexts of the land allocation systems in use. The units of analysis are the land allocation systems in use.

Data collection was through conducting one-on-one, in-depth, semi-structured, face-to-face interviews. All interviews were conducted in the respondents' respective home languages and were recorded, with the respondents' permission, for later transcription, translation to English, and analysis. Documentation was also acquired, including copies of PTO certificates, levy receipts and 
title deeds for those who possessed these as proof of ownership. Types of boundary demarcation used for residential and arable purposes were also directly observed.

In Matolweni village, 32 individual respondents were interviewed, each representing an individual household. Ten households were interviewed in KwaMvula village and in KwaSishwili, 27 households were interviewed. In Dinokana, 26 households were interviewed. Interviews were also conducted with the respective chiefs, headmen, sub-headmen, and ward councillors of the villages. In each case key informants were identified and a mix of random and snowball sampling was used: participants were initially randomly selected but the researchers found that participants were keen to direct them to people who they knew could better respond to their questions.

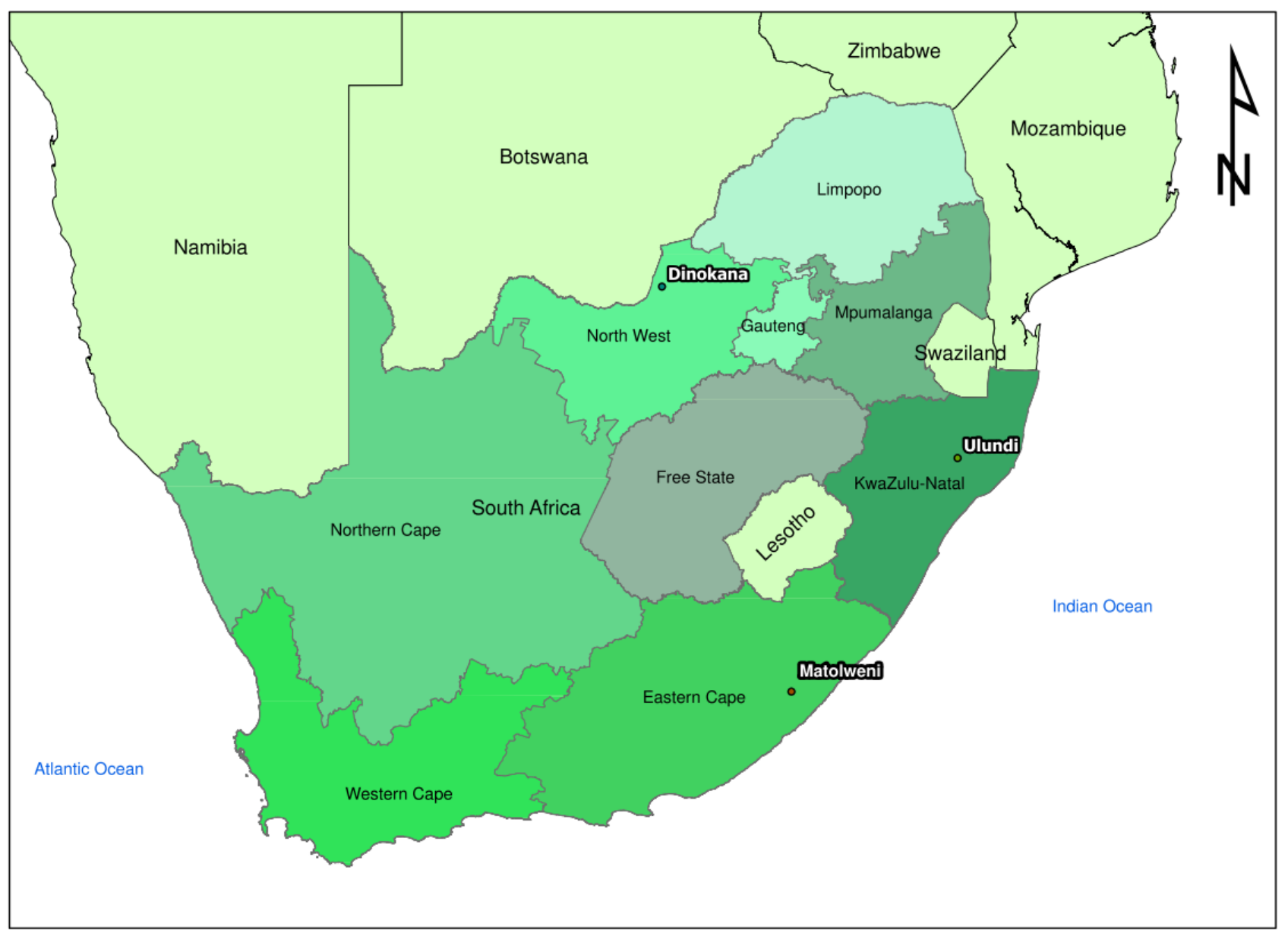

Figure 1 Locations of the case studies

\section{LAND MANAGEMENT IN THE CASE STUDY AREAS}

In keeping with the spirit of the grounded theory approach to qualitative data analysis as described by Hull (2014), with reference to Allan (2003) and Johannessen \& Hornbæk (2014), four themes have emerged from the data. These are described below under the 4 A's: Applicant, Authority, Acceptance, and Allocation. Questions associated with each theme are noted and these form useful guides to researchers investigating customary land allocation processes in South Africa with possible extension to other regions of sub-Saharan Africa. 


\subsection{Applicant - Who is applying for land?}

Applicants may be from the same community as the village to which they are applying for land, or they may be 'outsiders' and not part of that cultural group. In the former case, the applicant submits an expression of interest to the sub-headman. Following the chain of command is very important, and if the applicant goes directly to the tribal office or the chief it is considered an insult! Being a member of the community, the applicant is automatically eligible for an allocation of land, but their application will still be scrutinised and may be rejected.

For 'outsiders', a motivation and community support are required along with the application. The motivation takes the form of a letter of recommendation from the authority (chief or magistrate) in his place of origin (see also Alcock \& Hornby, 2004). Community support refers to backing by a relative or friend who is a member of the community. The applicants state the reasons for applying and reasons for seeking land in the village. Investigations by the sub-headman and/or the community are carried out to verify that the applicant is a person of good moral standing. The applicant should be a person of good moral standing, not a disturber of the peace, and not involved in witchcraft. Judgement in this regard is based on evidence received in the letters of recommendation and the community's knowledge of the applicant.

Although Whitehead \& Tsikata (2003) assert that social systems of land allocation differ with respect to gender, our findings suggest that both men and women may be allocated land in the study areas. In Matolweni and Ulundi, single women and widows may acquire land on their own, though inheritance is still patrilineal. In Dinokana, both men and women alike can inherit land.

\subsection{Authority - Who has the authority to grant access / use to land?}

Once the application has been submitted it moves through a hierarchy of traditional authority (social institutions) from sub-headman to headman to traditional council (a gathering of headmen presided over by the chief) and finally to the public institutions of local government and magistrates. In all case study areas the community members have substantial authority and although they are not the ultimate decision-makers, they have the ability to influence the decision. In all cases it was further reported that the representatives of social institutions (chiefs, headmen, etc.) were more geographically and socially accessible than the public institutions. The chiefs and their representatives live in and among the villagers, whereas public institutions are usually located in the nearest town.

\subsection{Acceptance - What are the criteria for acceptance / rejection of the application?}

An application for land rights is accepted only if the applicant is found to be no threat and has valid reasons for seeking land in the area. The application is assessed at various stages of the process and may either pass from that stage to the next and eventual acceptance or may be rejected. The stage at which an unsuccessful application is rejected will vary from case to case and may hinge either on the status of the land (e.g. unavailable due to a prior claim) or the applicant's credentials. 


\subsection{Allocation and Transfer Processes}

\subsubsection{How is the land parcel allocated to the applicant?}

In Matolweni, first the administrative fee is paid to the traditional authority, then the allocation fee is paid to the headman, and then the allocation ceremony may begin. The headman, subheadman, agricultural officers (abalimi), the neighbours and other locals must be present on the day of allocation. After the ceremony, the headman accompanies the applicant to the Provincial Department of Agriculture to get PTO certificates. The Department's responsibility is to issue the PTO certificates, demarcate land boundaries of residential and arable land, and keep records (including maps) showing the location of land parcels allocated. The PTO certificates are then taken to the Idutywa Magistrates Court for a stamp of approval.

In the KwaSishwili area of Ulundi, the traditional council allocates a plot to applicants whereas in KwaMvula, applicants can choose their own plot. Once the traditional council has approved the plot and application, a community meeting, which is actually a hand-over ceremony, is called at the site with the applicant providing drinks. The headman introduces the applicant to the community. He then gives the community, specifically the neighbours, a chance to accept or reject the application. Upon acceptance, the headman verbally explains the rules and regulations of the village to the applicant. The headman and his committee then demarcate the site boundaries in the presence of the applicant and the new neighbours. This is explained further below. Towards the end of the allocation process the applicant pays a registration fee to the traditional authority and an allocation fee to the headman. The headman issues a PTO certificate which contains the applicant's information and site description. A copy is retained at the traditional authority office, and the applicant is 'registered' with the traditional authority as a member of the community.

In Dinokana the applicant may first identify a piece of land for occupation, or they may request a plot from the sub-headman. Once a plot is identified the headman is informed of the application. He inspects the site and declares whether or not it is suitable for occupation, after which he identifies the boundaries of the site. He does this with input from the elders of the area. The applicant is then called before a weekly meeting of the local committee at the tribal office, and is expected to present his/her wish for a plot to them. The aim of this is to let the chief and his committee know that the headman has allocated the land and welcomed a member to his area, and any objection to this action should be made before proceeding. The applicant then pays an application fee to the tribal office and receives a receipt with the plot number and date of allocation. It is also expected that a token of appreciation is paid to the headman. For outsiders there is an additional fee to be paid.

\subsubsection{How are boundaries defined?}

The process of boundary demarcation follows after land has been allocated and occurs on the day of allocation in all cases except Dinokana, where it may happen at any point in the process. In Matolweni, officials from the Provincial Department of Agriculture (not registered surveyors) demarcate the boundaries at the hand-over ceremony at which all parties are present. Applicants cannot choose where they want their parcel to be and must accept the decision of the Department 
representatives and traditional authorities. In the Ulundi area it is the tribal representative, usually the sub-headman, who demarcates the boundaries, with the community and applicant as witnesses. The headman and representatives of his committee demarcate the boundaries in Dinokana.

In Matolweni, the Department of Agriculture ploughs a strip of land using a tractor along all four sides of the site. In Dinokana the headman gives a rough indication of where the corners of the site should be. In all cases, including KwaSishwili and KwaMvula, applicants are required to place stones at each corner of the site as beacons, preferably painted white. It is generally accepted that the new rights-holder should erect a permanent fence around his/her plot as soon as possible after allocation in order to secure their rights. Despite the rigorous participatory process of land allocation and boundary demarcation described, it seems that until the fence is erected the right to exclusive use of a parcel is not secured.

\subsubsection{What evidence is given concerning the applicant's rights to the land?}

In Matolweni, $72 \%$ of respondents have no documentary proof of their land rights. Only $14 \%$ of respondents could produce receipts of the administrative fee (which include the number of the allocated plot), and only $10 \%$ had copies of PTOs as proof. One respondent held a title deed issued prior to 1936. The traditional authority and the headmen keep records to avoid double allocations of land, as well as for collecting annual levies from the landholders. The Department of Agriculture also keeps a register of people who have been allocated land for residential or agricultural purposes and copies of the PTO certificates they issued. Hand drawn diagrams showing the land parcels and plot numbers are kept by the Department and these are helpful in cases of boundary disputes.

In the Ulundi area, all respondents indicated that they keep the PTO issued on the day of allocation, as well as receipts issued by the headman when paying fees, as proof of their rights to the land. The traditional authority is also supposed to retain a copy of the PTO certificates but this was not clearly ascertained in the study and requires follow-up.

The PTO system was never introduced in the Dinokana region. Residents of Dinokana keep only their receipts, including their names, plot numbers, and date of allocation. Only 7 respondents $(27 \%)$ could produce these when asked. The tribal office also keeps a copy of the receipt.

\subsubsection{How secure are the applicant's rights to the land?}

Overall, boundary-related disputes are rare in the areas studied. Three types of boundary disputes were reported: overlapping rights, denial of right of way, and boundary disagreements. Overlapping rights occur when an individual has been 'legitimately' allocated a piece of land but later someone else appears and claims that s/he has a right over the same land. This typically occurs when agricultural fields are allocated to people for either residential or agricultural purposes. The existence of such disputes reveals flaws in the system. Two respondents in KwaMvula (18\%) reported such disputes. Denial of right of way occurs when one neighbour has closed or narrowed a passage, often by fencing it, without obtaining the consent from neighbours who are using this right of way. This is essentially the changing of an agreed boundary without permission. In 
KwaSishwili, 4 respondents (15\%) reported this. Boundary disagreement is often the result of site boundaries not being clearly marked. When a neighbour erects a fence, an encroachment can result and lead to conflict. In Ulundi and Dinokana, boundaries are defined by the headman but placed by the applicant. This has resulted in the extension of the plot beyond the agreed size, which has resulted in conflict. Such boundary disagreements were reported by 6 respondents (22\%) in KwaSishwili, two $(18 \%)$ in KwaMvula, two (6\%) in Matolweni, and two (8\%) in Dinokana.

Disputes which cannot be resolved between the parties are handed over to the sub-headman or headman. The sub-headman visits the disputed field, and identifies where the boundary should be. If there are still disagreements the sub-headman measures each site, usually by pacing, with reference to whatever was recorded on the day of allocation. If still there is disagreement, the case passes to the headman and, failing resolution, to the tribal council where the chief makes a final resolution. In Dinokana it was reported that if the chief's resolution is not acted upon within the specified time then he will see to it that the boundary fence or wall is broken down. Claimants who feel they have been unjustly treated may take their case to the local magistrate's court, but as land rights are conferred by the chief to his subjects, the court defers to the chief's decision.

\section{EVALUATION OF TENURE SECURITY}

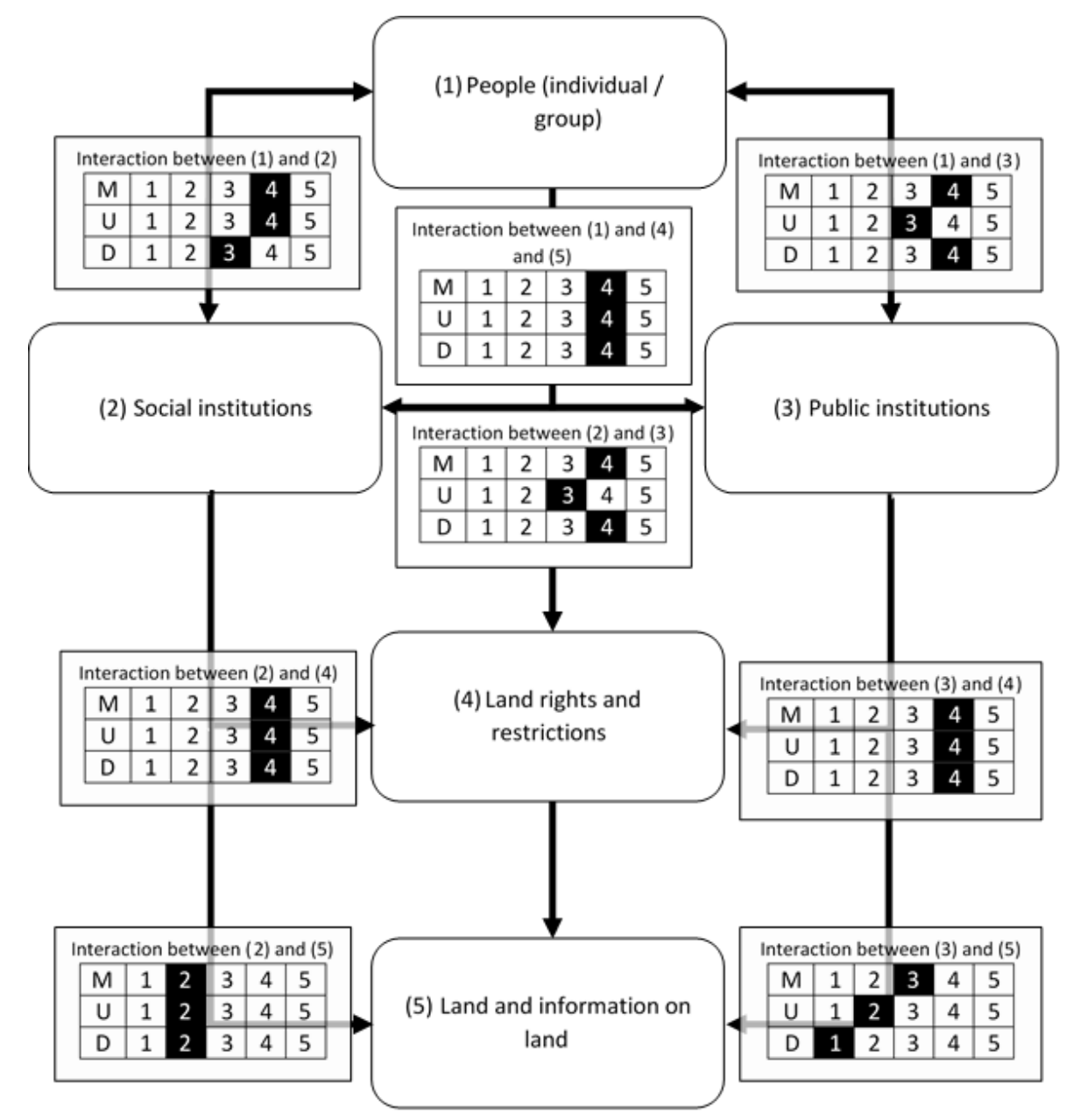

Figure 2 Modified model of tenure security, after Simbizi, Bennett \& Zevenbergen, 2014. (M, U, D refers to Matolweni, Ulundi, and Dinokana respectively.) 
According to Simbizi et al. (2014), several applications of their model are anticipated, including offering a theoretical basis for empirical investigation of the state of land tenure security. It is to this purpose that we have applied the model. Furthermore, the model is critiqued as to whether the elements and interactions identified in the model are as comprehensive as the authors claim. These questions will be answered by looking at each of the interactions between elements (see Figure 2).

\subsection{Interaction between people and social institutions}

Respondents recognise the social institutions to be reliable, and these institutions recognise the land rights of villagers; consequently the villagers put their faith in the institutions. Women's rights are recognised and men and women are equally eligible to acquire rights in land. Also the social institutions are located close to villagers' dwellings and are hence both geographically and socially accessible. With reference to the scale proposed in Section 1.4, this interaction is awarded a 4 for both Matolweni and Ulundi, but a tentative 3 for Dinokana as the evidence suggests that the chief takes a somewhat autocratic approach, as described in Section 3.4.4.

\subsection{Interaction between people and public institutions}

The public institutions for the three cases are the Department of Agriculture and Land Affairs in the Eastern Cape, the Ingonyama Trust and Ulundi Municipality in KwaZulu-Natal, and the local tribal and municipal offices in Dinokana. They have the role of keeping records of land information for people who have acquired rights to land. These records help in resolving cases of boundary disputes and in defending landholder rights. These public institutions recognise and protect people's rights to land. People in the Ulundi area, however, don't access these institutions directly but their interaction is through the social institutions. One of the reasons is that the public offices are located far from the villages. Hence for Matolweni and Dinokana, this interaction is awarded 4, but for Ulundi it is 3 .

\subsection{Interaction between public institutions and social institutions}

In Matolweni, the municipality has a representative in the village who works as an observer in land administration processes and works closely with the chief and the headman to inform them about development plans from the municipality. There is also an office for traditional leaders in the local municipality's offices. The traditional leaders take part in the municipality's meetings to discuss rural development projects. If the municipality plans to develop an area within a chief's jurisdiction then they have to ask for permission for such development to occur. Hence there is good interaction and mutual respect between these institutions and this interaction is awarded a 4 .

In Ulundi, the traditional council works very closely with the Ingonyama Trust Board, but not very closely with the Ulundi Municipality. But Ingonyama Trust works very closely with the Ulundi Municipality in dealing with issues regarding rural areas under municipal jurisdiction. Because the Ingonyama Trust has to act as an intermediary between the institutions, this interaction is awarded 3. 
In Dinokana, the local municipality is responsible for development in the area, but they must consult with the chief first. The decision to undertake major projects is taken to the community to discuss. The chief has the power to approve or reject any project proposed in the area. The municipality does not get involved in the land administration of the area, they only maintain public properties that are in the area. The evidence suggests that there is good interaction between these social and public institutions and each knows the roles they are expected to play and respects the authority of the other, hence this interaction is awarded a 4 .

\subsection{Interaction between people, rights and land}

Although the model states that people's tenure is secure if they perceive it to be secure (Simbizi, Bennett \& Zevenbergen, 2014), Whittal (2014) has highlighted that perception of security is not the same as actual tenure security. Despite this criticism, perception of tenure security is here evaluated as it is a component of the critiqued model. Overall, the three cases are rated at a 4 for the perception of tenure security as described below.

People in Matolweni perceive their tenure to be secure. The villagers trust the system of land administration and the traditional systems of demarcating boundaries. They believe that no one could evict them from their land and take their land away from them because they have occupied the land for a significant length of time and they have developed a significant attachment to the land. This result is somewhat surprising given that $72 \%$ of respondents have no documentary proof of their right to land. However, when asked the reason for trusting the system, they responded that it is the only system they know and it has been in existence for many years. This may give weight to Whittal's objection noted above.

People in KwaMvula village also indicate a strong perception of tenure security. There is trust in the system and respect for the authorities that administer land. In KwaShiwili, the perception of tenure security is less strong. Being closer to the town of Ulundi there was a perceived but unsubstantiated threat that the municipality would take over their land as the town expanded. Yet, regardless of this, their land rights are perceived to be secure overall.

In Dinokana the overall impression is also one of security, although some expressed dissatisfaction with the manner in which the chief administers the land and only $27 \%$ of respondents could produce records of their rights to land.

\subsection{Interactions between institutions and rights}

According to Simbizi et al's model (2014: 236), the institutions should "recognise, protect and enforce" a range of rights and restrictions along the continuum of rights. These are restricted to land rights only, with cognisance of what this implies (see e.g. Gilbert, 2013). In the study areas, occupation and use rights (limited to grazing and farming) are the most pertinent, although rights to use land for business purposes were also reported in Dinokana. Both the public and social institutions recognise these rights, so these interactions are awarded a 4 for all cases. 


\subsection{Interactions between institutions and land}

The institutions regulate and recognise physical land (Simbizi, Bennett \& Zevenbergen, 2014) through their involvement in the land allocation process, so this interaction is affirmed. Public institutions also record information about the allocation of land, and the reference to maps of plots in Matolweni indicates that there is a reasonably sophisticated and comprehensive system in place. There is no indication that the public institutions keep records of allocations in Dinokana, although the tribal office keeps copies of receipts. In Ulundi both public and social institutions are supposed to keep copies of the PTOs issued, though for the latter it is not clear how reliably this is done and further investigation is required. Hence the interaction between public institutions and land is awarded a 3 for Matolweni (due to the reference to maps) and a 1 for Dinokana (due to there being no mention of public institution involvements at this level). All other interactions are awarded a 2 because too much emphasis is placed on local knowledge and there is no other recorded use of a map (rudimentary cadastre).

\section{CONCLUSIONS}

In spite of geographical, language and cultural differences between the case study areas, there is marked similarity in terms of the processes of land access, boundary demarcation and dispute resolution. The two institutional groups (public and social) generally work together to ensure that land use rights are managed effectively and that individuals and communities to which they belong are able to enjoy their land use rights. Property boundaries are mostly clearly defined and the process is open and participatory. Hence there are few serious boundary disputes between neighbours. There is a strong perception of tenure security overall. Traditional authorities fulfil the role of being the custodians of rural land, and they do this on behalf of the state. Testimonies from community members and documents are used as evidence of land rights and to settle disputes as fairly as possible. The word of the chief is final.

The public and social institutions recognise and regulate the land rights of people in a satisfactory manner. As a result there is trust in the system of land administration and management, and perceptions of tenure security are high. All five elements of tenure security identified in Simbizi et al (2014) do exist in the cases studied. Interactions between elements of the model are mostly positive. The use of the five-point scale as opposed to a checkbox, while admittedly subjective, is deemed to be an improvement on the original model. The scale allows the researcher to rate the level of interaction between the elements and is useful for comparing one case against another. In order to make the rating more objective, an assessment matrix such as that of Agunbiade, Rajabifard and Bennett (2014) could be used to formulate interview-guiding questions.

We have given a description of three case study areas with different cultural systems of tribal authority in South Africa. Land tenure security was assessed using a theoretical model, but the accuracy of this assessment cannot be concluded without further research, possibly using an alternative model or models (such as that of Whittal (2014)). Naturalistic generalization to other cases of similar cultural group tribal authority in South Africa may be possible, but replication will 
be strengthened by further case studies, particularly in other cultural group areas. The effect of South Africa's land reform policy and the replacement of PTOs with freehold tenure (Louw, 2013) is not considered part of this research, but adds another layer of complexity to the issues of land administration and can be included in future work.

\section{ACKNOWLEDGEMENTS}

The authors gratefully acknowledge financial assistance provided by the Department of Rural Development and Land Reform as well as the University of Cape Town.

\section{REFERENCES}

Agunbiade, M.E., Rajabifard, A. \& Bennett, R. 2014. Land administration for housing production: An approach for assessment. Land Use Policy, vol. 38, pp. 366-377. DOI: 10.1016/j.landusepol.2013.12.005.

Alcock, R. \& Hornby, D. 2004. Traditional Land Matters - a look into Land Administration in Tribal Areas in Kwazulu-Natal, Land Entity Assessment Project.

Allan, G. 2003. A critique of using grounded theory as a research method. Journal of Business Research, vol. 2 no. 1, pp. 1-10.

Barry, M. \& Danso, E.K. 2014. Tenure security, land registration and customary tenure in a peri-urban Accra community. Land Use Policy, vol. 39, pp. 358-365. DOI: 10.1016/j.landusepol.2014.01.017.

Bennett, R., Rajabifard, A., Kalantari, M., Wallace, J. \& Williamson, I. 2010. Cadastral futures: building a new vision for the nature and role of cadastres. In FIG Congress 2010: Facing the challenges - Building the capacity. Sydney, Australia, International Federation of Surveyors, viewed 19 July 2013, <http://www.fig.net/pub/fig2010/papers/ts08k/ts08k_bennett_rajabifard_et_al_4096.pdf>.

Burns, A., Grant, C., Nettle, K., Brits, A. \& Dalrymple, K. 2006. LAND ADMINISTRATION REFORM: Indicators of Success, Future Challenges. Wollongong: Land Equity International.

Cousins, T. \& Hornby, D. 2006. The Realities of Tenure Diversity in South Africa. In Colloque International "Les frontieres de la question foncière-At the Frontier of Land Issues". Montpellier, viewed 30 April 2013, <http://www.mpl.ird.fr/colloque_foncier/Communications/PDF/Cousins T.pdf>.

Cousins, T., Pollard, S. \& du Toit, D. 2007. Legislation in relation to land, water and natural resource governance in communal land in South Africa, viewed 29 July 2015, <http://award.org.za/wpcontent/uploads/sites/2/2014/03/Legislation-in-relation-to-land-water-and-natural-resource-governance-incommunal-land-in-South-Africa..pdf $>$.

Department of Science and Technology. 2015. Protection, Promotion, Development and Management of Indigenous Knowledge Systems Bill. Pretoria, South Africa: Department of Science and Technology, viewed 23 November 2014, <http://www.gov.za/sites/www.gov.za/files/38574_gen243.pdf>.

Enemark, S. 2005. Understanding the Land Management Paradigm. In FIG Commission 7 Symposium on Innovative Technologies for Land Administration. Madison, Wisconsin: International Federation of Surveyors. Viewed 5 April 2013, <http://www.fig.net/council/enemark_papers/madison_2005.pdf>.

Fox, J. a. 2015. Social Accountability: What Does the Evidence Really Say? World Development, vol. 72, pp. 346-361. DOI: 10.1016/j.worlddev.2015.03.011.

Gilbert, J. 2013. Land Rights as Human Rights: the case for a specific right to land. International Journal on Human Rights, vol. 10, no. 18, pp. 115-136.

Gorjestani, N. 2004. INDIGENOUS KNOWLEDGE FOR DEVELOPMENT: OPPORTUNITIES AND CHALLENGES. In Protecting and Promoting Traditional Knowledge: systems, national experiences and international dimensions. S. Twarog \& P. Kapoor, Eds. New York, USA: United Nations. Pp. 265-271.

Hull, S. 2014. Analysing the Cadastral Template Using a Grounded Theory Approach. In AfricaGEO. Cape Town: CONSAS Conference. $\quad$ Viewed $21 \quad$ July 
<http://www.africageoproceedings.org.za/?page_id=473>.

Hull, S. \& Whittal, J. 2013. Good e-Governance and Cadastral Innovation: In Pursuit of a Definition of eCadastral Systems. South African Journal of Geomatics, vol. 2, no. 4, pp. 342-357.

Johannessen, G.H.J. \& Hornbæk, K. 2014. Must evaluation methods be about usability? Devising and assessing the utility inspection method. Behaviour \& Information Technology, vol. 33, February, pp. 195206. DOI: 10.1080/0144929X.2012.751708.

Kitchin, F. \& Ovens, W. 2013. Land Governance in South Africa: Implementing the Land Governance Assessment Framework. Urban LandMark. Viewed 1 October 2014, 〈http://www.urbanlandmark.org.za/downloads/lgaf_booklet.pdf >.

Louw, L. 2013. Land reform - and rapidly! PositionIT. September, pp. 6-8. Viewed 23 November 2015, <http://www.ee.co.za/article/land-reform-and-rapidly.html>.

Masango, C. 2010. Indigenous traditional knowledge protection: prospects in South Africa's intellectual property framework? South African Journal of Libraries and Information Science. Vol. 76, no. 1, pp. 74-80.

Owusu-Ansah, F.E. \& Mji, G. 2013. African indigenous knowledge and research. African Journal of Disability, vol. 2, no. 1, pp. 1-5. DOI: 10.4102/ajod.v2i1.30.

Riba, M. 2010. Cadastral Template - South Africa. Viewed 17 May 2013, <http://www.cadastraltemplate.org/countryreport/SouthAfrica-4Aug2010.pdf>.

Simbizi, M.C.D., Bennett, R.M. \& Zevenbergen, J. 2014. Land tenure security: Revisiting and refining the concept for Sub-Saharan Africa's rural poor. Land Use Policy, vol. 36, pp. 231-238. DOI: 10.1016/j.landusepol.2013.08.006.

Törhönen, M.-P. 2004. Sustainable land tenure and land registration in developing countries, including a historical comparison with an industrialised country. Computers, Environment and Urban Systems, vol. 28, no. 5, pp. 545-586. DOI: 10.1016/j.compenvurbsys.2003.11.007.

Twarog, S. \& Kapoor, P. Eds. 2004. Protecting and Promoting Traditional Knowledge: systems, national experiences and international dimensions. New York, USA: United Nations. Viewed 23 November 2015, <http://www.unctad.org/en/docs//ditcted10_en.pdf>.

UN-HABITAT. 2008. Secure land rights for all. Nairobi, Kenya: UN-HABITAT.

Weideman, M. 2004. Land reform, equity and growth in South Africa: A comparative Analysis, $\mathrm{PhD}$ thesis, University of the Witwatersrand. Viewed 1 October 2014, <http://wiredspace.wits.ac.za/handle/10539/275>.

van Asperen, P. 2014. Evaluation of innovative land tools in sub-Saharan Africa: Three cases from a periurban context, $\mathrm{PhD}$ thesis, Delft University Press.

van Leeuwen, M. 2014. Renegotiating customary tenure reform - Land governance reform and tenure security in Uganda. Land Use Policy, vol. 39, pp. 292-300. DOI: 10.1016/j.landusepol.2014.02.007.

Whitehead, A. \& Tsikata, D. (2003), Policy discourses on women's land rights in sub-Saharan Africa: the implications of the re-turn to the customary. Journal of Agrarian Change, vol. 3, pp. 67-112.

Whittal, J. 2014. A New Conceptual Model for the Continuum of Land Rights. South African Journal of Geomatics, vol. 3, no. 1, pp. 13-32.

Williamson, I., Enemark, S., Wallace, J. \& Rajabifard, A. 2010. Land administration for sustainable development. Redlands, California: Esri Press.

Zevenbergen, J. 2002. Systems of Land Registration: Aspects and Effects, PhD thesis, Delft University of Technology.

Ziqubu, N., Cousins, T. \& Hornby, D. 2001. Using local practices and records to secure individual tenure rights in common property situations - Lessons from the case studies on what might work on the ground. In Department of Land Affairs' National Land Tenure Conference. Durban: Association for Rural Advancement. 